\title{
Enterococcus gallinarum meningitis: a case report and literature review
}

\author{
Bo Zhao, Mao Sheng Ye and Rui Zheng*
}

\begin{abstract}
Background: As an opportunistic pathogen, E. gallinarum mainly leads to nosocomial infections, and it's multi-drug resistance has gained more and more attention. Central nervous system infections caused by E. gallinarum are rare, but have been reported more often in recent years. The previous cases were generally secondary to neurosurgery, especially ventriculoperitoneal shunts. In recent years, the cases largely occurred in patients with impaired immune function. The patient in our report may have had dual risk factors (immune impairment and an invasive surgical procedure).

Case presentation: The patient, a 35-year-old female, was admitted to our hospital for headaches of 3 days duration accompanied by nausea and vomiting for 2 days. The patient had fevers and chills for 3 days before admission; the peak body temperature was $38.5^{\circ} \mathrm{C}$. The patient had a splenectomy in our hospital 2 years earlier for thrombocytopenia and was thought to be immunocompromised. The abnormal findings on physical examination and laboratory testing were as follows: neck stiffness, present; lumbar puncture: pressure, $300 \mathrm{mmH}_{2} \mathrm{O}$; Pandy's test, positive; white blood cell (WBC) count, $1536 \times 10^{6} / \mathrm{L}$; monocyte count, $602 \times 10^{6} / \mathrm{L}$; monocyte percentage, 39.2\%; multinucleate cell count, $934 \times 10^{6} / \mathrm{L}$; multinucleate cell percentage, $60.8 \%$; protein, $1.08 \mathrm{~g} / \mathrm{L} ; \mathrm{WBC}$ count, $21.1 \times 10^{9} / \mathrm{L}$; neutrophil percentage, 85.3\%; neutrophil count, $20.55 \times 10^{9} / \mathrm{L} ; \mathrm{C}$ reactive protein (CRP): $136.4 \mathrm{mg} / \mathrm{L}$; procalcitonin, 6 . $70 \mathrm{ng} / \mathrm{mL}$. The patient was given meropenem ( $2.0 \mathrm{~g}$, intravenous infusion, every $8 \mathrm{~h}$ ) for anti-infection supplemented with other symptomatic support treatments. The patient's fever and headache had no significant relief.

Conclusions: Central nervous system infections caused by E. gallinarum are rare, but should be suspected, particularly inpatients with impaired immune function or ineffective treatment. Avoiding long-term invasive treatment and improving immunity are helpful to reduce the occurrence of E. gallinarum infections. Early detection and diagnosis, as well as rational antibiotic use, are the keys to achieve satisfactory efficacy.
\end{abstract}

Keywords: Enterococcus gallinarum meningitis, Infections

\section{Background}

As an opportunistic pathogen, E. gallinarum mainly leads to nosocomial infections, and it's multi-drug resistance has gained more and more attention. Central nervous system infections caused by E. gallinarum are rare, but have been reported more often in recent years. The previous cases were generally secondary to neurosurgery, especially ventriculoperitoneal shunts. In recent years, the cases largely occurred in patients with impaired immune function. The patient in our report may have had dual risk factors (immune impairment and an invasive surgical procedure).

\footnotetext{
* Correspondence: zhengr@sj-hospital.org

Department of Respiratory Medicine, Shengjing Hospital of China Medical University, Shenyang, China
}

(c) The Author(s). 2018 Open Access This article is distributed under the terms of the Creative Commons Attribution 4.0 International License (http://creativecommons.org/licenses/by/4.0/), which permits unrestricted use, distribution, and reproduction in any medium, provided you give appropriate credit to the original author(s) and the source, provide a link to the Creative Commons license, and indicate if changes were made. The Creative Commons Public Domain Dedication waiver

\section{Case presentation}

The patient, a 35-year-old female, was admitted to our hospital for evaluation of headaches of 3 days duration accompanied by nausea and vomiting for 2 days. The patient had fevers and chills for 3 days before admission; the peak body temperature was $38.5{ }^{\circ} \mathrm{C}$. 2 days before admission, the patient developed headaches, which were persistent and intolerable, accompanied by four episodes of vomiting. The patient had a splenectomy in our hospital 2 years earlier for thrombocytopenia and was thought to be immunocompromised. The findings on physical examination, imaging, and laboratory testing after admission were as follows: skin and mucous, normal; heart, lung, and abdomen, normal; neck stiffness, present; Kernig's sign, negative; lumbar puncture: pressure, $300 \mathrm{mmH}_{2} \mathrm{O}$; Pandy's test, positive; white blood cell \footnotetext{
(http://creativecommons.org/publicdomain/zero/1.0/) applies to the data made available in this article, unless otherwise stated.
} 
(WBC) count, $1536 \times 10^{6} / \mathrm{L}$; monocyte count, $602 \times 10^{6} / \mathrm{L}$; monocyte percentage, 39.2\%; multinucleate cell count, $934 \times 10^{6} / \mathrm{L}$; multinucleate cell percentage, $60.8 \%$; protein, $1.08 \mathrm{~g} / \mathrm{L}$ (Table 1); head and chest CT, normal; head contrast MRI + MRA + MRV, normal; WBC count, $21.1 \times 10^{9} / \mathrm{L}$; neutrophil percentage, $85.3 \%$; neutrophil count, $20.55 \times 10^{9} / \mathrm{L}$; C reactive protein (CRP): $136.4 \mathrm{mg} / \mathrm{L}$; procalcitonin, $6.70 \mathrm{ng} / \mathrm{mL}$; liver and kidney function, normal; and electrolytes, normalMeropenem $(2.0 \mathrm{~g}$ intravenous infusion every $8 \mathrm{~h}$ ) was administered with other symptomatic support treatments, such as reducing intracranial pressure by mannitol. The temperature fluctuated around $38{ }^{\circ} \mathrm{C}$. There was no significant relief from the headaches. A lumbar puncture was repeated 6 days after admission. The cerebrospinal fluid culture and drug sensitivity testing showed an Enterococcus gallinarum infection and sensitivity to linezolid (Table 2), respectively. Thus, an intravenous infusion of linezolid $(0.6 \mathrm{~g}$ every $12 \mathrm{~h})$ was administered. On the second day of linezolid, the temperature began to decrease. After 3 weeks of anti-E. gallinarum treatment, the temperature returned to normal and the headache resolved. A lumbar puncture was repeated three times. The cerebrospinal fluid was colorless and transparent, the pressure and WBC count were decreased, and the bacterial cultures were negative.
The patient was discharged from the hospital when stable and in good condition.

\section{Discussion and conclusions}

Enterococcus gallinarum was first isolated from the gut of a chicken. Enterococcus gallinarum is normal flora in human and animal guts [1]. In recent years, with the increasing use of broad-spectrum antibiotics and invasive medical devices, infections caused by E. gallinarum have gradually increased, and multi-drug resistance has gained more and more attention. In 2010, among the isolated strains of Enterococcus in several Chinese hospitals, E. gallinarum accounted for $1.9 \%$ of isolates, and second only to E. faecalis and E. faecium [2]. As an opportunistic pathogen, E. gallinarum mainly leads to nosocomial infections, including urinary tract, abdominal, biliary tract, and a small percentage of bloodstream infections. Patients who undergo invasive operations or are immunosuppressed are susceptible [3, 4]. Central nervous system infections caused by $E$. gallinarum are rare, but have been reported more often in recent years.

Symptoms of E. meningitis include fevers and headaches, which may be accompanied by a disturbance of consciousness or even convulsions. Some patients may have septic shock, focal neurologic deficits, petechial

Table 1 Results of lumbar puncture after admission

\begin{tabular}{|c|c|c|c|c|c|}
\hline Lumbar puncture & 1st day & 6th day & 14th day & 22nd day & 31st day \\
\hline Pressure $\mathrm{mmH}_{2} \mathrm{O}(80-180)$ & 300 & 300 & 160 & 110 & 110 \\
\hline $\begin{array}{l}\text { Appearance } \\
\text { (Colorless and transparent) }\end{array}$ & $\begin{array}{l}\text { Colorless and } \\
\text { transparent }\end{array}$ & $\begin{array}{l}\text { Light yellow } \\
\text { and transparent }\end{array}$ & $\begin{array}{l}\text { Colorless and } \\
\text { transparent }\end{array}$ & $\begin{array}{l}\text { Colorless and } \\
\text { transparent }\end{array}$ & $\begin{array}{l}\text { Colorless and } \\
\text { transparent }\end{array}$ \\
\hline Pandy's test $(-)$ & + & + & Weak positive & Weak positive & - \\
\hline WBC count $10^{6} / \mathrm{L}(0-8)$ & 1536 & 204 & 107 & 36 & 11 \\
\hline $\begin{array}{l}\text { Monocyte count } 10^{6} / \mathrm{L} \\
\text { (not available) }\end{array}$ & 602 & 164 & 106 & 36 & 10 \\
\hline $\begin{array}{l}\text { Monocyte percentage \% } \\
\text { (not available) }\end{array}$ & 39.2 & 92.1 & 99.1 & 100.0 & 97.9 \\
\hline $\begin{array}{l}\text { Multinucleate cell count } 10^{6} / \mathrm{L} \\
\text { (not available) }\end{array}$ & 934 & 40 & 1 & 0 & 1 \\
\hline $\begin{array}{l}\text { Multinucleate cell percentage \% } \\
\text { (not available) }\end{array}$ & 60.8 & 7.9 & 0.9 & 0 & 2.1 \\
\hline RBC count $10^{6} / \mathrm{L}(0)$ & 0 & 0 & 0 & 0 & 0 \\
\hline Glucose mmol/L (2.5-4.5) & $\begin{array}{l}3.21 \\
\text { (RBG 6.80) }\end{array}$ & $\begin{array}{l}2.32 \\
\text { (BG not tested) }\end{array}$ & $\begin{array}{l}3.33 \\
\text { (FBG 5.71) }\end{array}$ & $\begin{array}{l}3.03 \\
\text { (BG not tested) }\end{array}$ & $\begin{array}{l}3.1 \\
(\text { FBG 4.54) }\end{array}$ \\
\hline Chlorine mmol/L (120-132) & 121.5 & 115 & 120.0 & 118.2 & 119.7 \\
\hline Protein g/L (0.15-0.45) & 1.08 & 0.84 & 0.52 & 0.41 & 0.33 \\
\hline $\begin{array}{l}\text { Cryptococcus smear } \\
\text { (Ink stain) }\end{array}$ & - & - & - & - & - \\
\hline $\begin{array}{l}\text { Mycobacterium tuberculosis smear } \\
\text { (Acid-fast stain) }\end{array}$ & - & - & - & - & - \\
\hline Bacterial smear (Gram's stain) & - & - & - & - & - \\
\hline Bacterial culture (Plate cultivation) & - & Enterococcus gallinarum & - & - & - \\
\hline
\end{tabular}


Table 2 The susceptibility results of E.gallinarum

\begin{tabular}{|c|c|c|c|c|c|c|}
\hline \multirow[t]{2}{*}{ Antibiotic name } & \multirow[t]{2}{*}{ Method } & \multirow[t]{2}{*}{ Result } & \multirow[t]{2}{*}{ Sensitivity } & \multicolumn{3}{|c|}{ Determination standard } \\
\hline & & & & Sensitive & Intermediary & Resistance \\
\hline Penicillin G & MIC & 8.0 & S & $\geq 16$ & & $\leq 8$ \\
\hline Vancomycin & MIC & 2.0 & R & $\geq 32$ & $8-16$ & $\leq 4$ \\
\hline Linezolid & MIC & 1.0 & S & $\geq 8$ & 4 & $\leq 2$ \\
\hline Tetracycline & MIC & $\geq 16.0$ & $\mathrm{R}$ & $\geq 16$ & 8 & $\leq 4$ \\
\hline Ciprofloxacin & MIC & $\leq 0.5$ & S & $\geq 4$ & 2 & $\leq 1$ \\
\hline Erythromycin & MIC & 8.0 & R & $\geq 8$ & $1-4$ & $\leq 0.5$ \\
\hline Levofloxacin & $\mathrm{MIC}$ & 1.0 & S & $\geq 8$ & 4 & $\leq 2$ \\
\hline Ampicllin & MIC & $\leq 2.0$ & S & $\geq 16$ & & $\leq 8$ \\
\hline Quinupristin/Dalfopristin & $\mathrm{MIC}$ & 1.0 & $\mathrm{R}$ & $\geq 4$ & 2 & $\leq 1$ \\
\hline Clindamycin & MIC & $\geq 8.0$ & R & $\geq 4$ & $1-2$ & $\leq 0.5$ \\
\hline Moxifloxacin & $\mathrm{MIC}$ & $\leq 0.25$ & S & $\geq 4$ & 2 & $\leq 1$ \\
\hline Tigecycline & MIC & $\leq 0.12$ & S & & & $\leq 0.25$ \\
\hline Gentamicin-High & $\mathrm{MIC}$ & & S & & & \\
\hline Streptomycin-High & MIC & & $\mathrm{R}$ & & & \\
\hline
\end{tabular}

MIC minimal inhibitory concentration, $R$ resistance, $S$ sensitive

Table 3 Enterococcus gallinarum meningitis reports in the literature

\begin{tabular}{|c|c|c|c|c|c|c|c|}
\hline Reference & Country & Gender & Age & Symptoms & Susceptibility factors & Treatment & Outcome \\
\hline $\begin{array}{l}\text { Yoko Takayama, } \\
\text { et al. [8] } 2003\end{array}$ & Japan & Male & 57 years & $\begin{array}{l}\text { Fever } \\
\text { Neck stiffness }\end{array}$ & $\begin{array}{l}\text { VP shunt for subarachnoid } \\
\text { hemorrhage } \\
\text { Rheumatoid arthritis } \\
\text { with prednisolone and } \\
\text { anti-rheumatic drugs }\end{array}$ & $\begin{array}{l}\text { i.v. teicoplanin for } \\
4 \text { weeks } \\
\text { VP shunt removal }\end{array}$ & Cured \\
\hline $\begin{array}{l}\text { Yoko Takayama. } \\
\text { et al. [8] } 2003\end{array}$ & Japan & Male & 12 years & $\begin{array}{l}\text { Fever } \\
\text { Drowsy } \\
\text { Limb cramps }\end{array}$ & VP shunt for astrocytoma & $\begin{array}{l}\text { i.v. ampicillin for } \\
8 \text { weeks } \\
\text { VP shunt replaced }\end{array}$ & Cured \\
\hline $\begin{array}{l}\text { Asok Kurup, } \\
\text { et al. [9] } 2001\end{array}$ & Singapore & Male & 64 years & $\begin{array}{l}\text { Fever } \\
\text { Drowsy }\end{array}$ & $\begin{array}{l}\text { VP shunt for multi-loculated } \\
\text { hydrocephalus }\end{array}$ & $\begin{array}{l}\text { i.v. ampicillin and } \\
\text { gentamicin for } 3 \text { weeks }\end{array}$ & Cured \\
\hline $\begin{array}{l}\text { Fahmi Yousef Khan, } \\
\text { et al. [10] } 2011\end{array}$ & Pakistan & Female & 53 years & $\begin{array}{l}\text { Fever } \\
\text { Headache } \\
\text { Consciousness disturbance } \\
\text { Neck stiffness }\end{array}$ & $\begin{array}{l}\text { Decompression craniotomy } \\
\text { for cerebral hemorrhage }\end{array}$ & i.v. linezolid for 3 weeks & Cured \\
\hline $\begin{array}{l}\text { Vicente Sperb } \\
\text { Antonello, } \\
\text { et al. [11] } 2010\end{array}$ & Brazil & Male & 53 years & $\begin{array}{l}\text { Mental confusion } \\
\text { Fever } \\
\text { Ataxia } \\
\text { Neck stiffness }\end{array}$ & Alcohol abuse & $\begin{array}{l}\text { i.v. ampicillin and } \\
\text { gentamycin for } 3 \text { weeks }\end{array}$ & Cured \\
\hline $\begin{array}{l}\text { B. Roca, } \\
\text { et al. [12] } 2006\end{array}$ & Spain & Female & 51 years & $\begin{array}{l}\text { Fever } \\
\text { Headache }\end{array}$ & $\begin{array}{l}\text { Cerebrospinal fluid drainage } \\
\text { catheter for persistent right } \\
\text { nostril rhinorrhea }\end{array}$ & $\begin{array}{l}\text { i.v. ampicillin and } \\
\text { rifampin for } 3 \text { weeks } \\
\text { Drain removal }\end{array}$ & Cured \\
\hline $\begin{array}{l}\text { Po-Yi Paul Su, } \\
\text { et al. [5] } 2016\end{array}$ & USA & Male & 53 years & $\begin{array}{l}\text { Fever } \\
\text { Neck stiffness }\end{array}$ & $\begin{array}{l}\text { Acute lymphoblastic B cell } \\
\text { leukemia with chemotherapy } \\
\text { Neutropenic } \\
\text { Broad-spectrum antibiotics } \\
\text { usage } \\
\text { Type } 2 \text { diabetes mellitus }\end{array}$ & $\begin{array}{l}\text { i.v. ampicillin and } \\
\text { ceftriaxone for } 4 \text { weeks }\end{array}$ & Cured \\
\hline $\begin{array}{l}\text { Quanxiao Li, } \\
\text { et al. [13] } 2013\end{array}$ & China & Male & 2 days & $\begin{array}{l}\text { Fever } \\
\text { Hypermyotonia }\end{array}$ & Neonatal hemolysis & i.v. linezolid for 3 weeks & Cured \\
\hline
\end{tabular}


rashes, and meningeal irritation [4]. High value of CRP and procalcitonin can be found in patients with E. gallinarum meningitis. The diagnosis of E. gallinarum meningitis is based on clinical symptoms, cerebrospinal fluid examination, and pathogen culture. PCR is also used for diagnosis, the results of which can be obtained $48 \mathrm{~h}$ earlier than routine bacterial cultures [5]. The patient in this report exhibited fevers, headaches, and neck stiffness. The cerebrospinal fluid was purulent and the culture confirmed an infection with E. gallinarum. The patient had undergone a splenectomy and her immunoglobulin level was lower than the normal value, suggesting impairment of humoral immune function, which increased her risk for opportunistic infections [6]. The cerebrospinal fluid culture after the first lumbar puncture was negative, and the possibility that the pathogen was introduced by the first lumbar puncture could not be excluded. Moreover, the administration of broad-spectrum antibiotics may have exacerbated the infection.

There have been eight E. gallinarum meningitis cases reported worldwide (Table 3). The previous cases were generally secondary to neurosurgery, especially ventriculoperitoneal shunts. In recent years, the cases largely occurred in patients with impaired immune function. The patient in our report may have had dual risk factors (immune impairment and an invasive surgical procedure).

Enterococcus gallinarum carries the vanC drug-resistance gene and has a high rate of resistance for vancomycin (82.1\%). The pathogen is relatively sensitive to teicoplanin and linezolid [2]. The strains carrying the van $\mathrm{A}$ or $\operatorname{van} \mathrm{B}$ resistance genes have been isolated, and are resistant to vancomycin and teicoplanin.[7]. Based on drug sensitivity testing, we chose linezolid at an adequate dose and time to treat the patient. The course of linezolid generally lasts 3 weeks or longer, and the prognosis is good. We recommended a 3-week course of linezolid and obtained satisfactory efficacy. The symptoms, signs, and follow-up results of the cerebrospinal fluid were all remarkably improved after treatment. The patient did not relapse after treatment was completed.

Avoiding long-term invasive treatment and improving immunity are helpful to reduce the occurrence of $E$. gallinarum infections. Early detection and diagnosis, as well as rational antibiotic use, are the keys to achieve satisfactory efficacy.

\section{Authors' contributions}

BZ and MSY collected and analyzed medical data of the patient. BZ and RZ wrote and revised the manuscript. RZ made a critical revision of the manuscript for important intellectual content. All authors read and approved the final manuscript.

Ethics approval and consent to participate Not Applicable.

\section{Consent for publication}

The patient gave a written consent for publication of her potentially identifying information.

\section{Competing interests}

The authors declare that they have no competing interests.

\section{Publisher's Note}

Springer Nature remains neutral with regard to jurisdictional claims in published maps and institutional affiliations.

Received: 1 June 2017 Accepted: 15 May 2018

Published online: 21 May 2018

References

1. Oladipo IC, Sanni Al, Writachit C, Chakravorty S, Jana S, Rudra DS, et al. Bioprotective potential of bacteriocinogenic enterococcus gallinarum strains isolated from some Nigerian fermented foods, and of their bacteriocins. Pol J Microbiol. 2014;63(4):415-22.

2. Yang Qing YY, Yuxing NI. CHINET 2010 surveillance of antibiotic resistance in enterococcus in China. Chin J Infect Chemother. 2012;12(2):92-7.

3. HOU Hui-ling NX-h. Analysis of clinical characteristic and drug resistance of infected cases due to enterococcus gallinarum (a 35-case report). J Clin Pulm Med. 2010;15(3):308-9.

4. O'Driscoll T, Crank CW. Vancomycin-resistant enterococcal infections: epidemiology, clinical manifestations, and optimal management. Infect Drug Resist. 2015;8:217-30

5. Su PY, Miller S, Rutishauser RL, Babik J. Broad-range PCR for early diagnosis of nosocomial enterococcus gallinarum meningitis. Infect Dis (Lond). 2016; 48(8):640-2.

6. Japanese Respiratory Society. Pneumonia in immunocompromised patients. Respirology. 2009;14(Suppl 2):S44-50.

7. Eshaghi A, Shahinas D, Li A, Kariyawasam R, Banh P, Desjardins M, et al. Characterization of an enterococcus gallinarum isolate carrying a dual vanA and vanB cassette. J Clin Microbiol. 2015;53(7):2225-9.

8. Takayama Y, Sunakawa K, Akahoshi T. Meningitis caused by enterococcus gallinarum in patients with ventriculoperitoneal shunts. J Infect Chemother. 2003;9(4):348-50.

9. Kurup A, Tee WS, Loo LH, Lin R. Infection of central nervous system by motile enterococcus: first case report. J Clin Microbiol. 2001;39(2):820-2.

10. Khan FY, Elshafi SS. Enterococcus gallinarum meningitis: a case report and literature review. J Infect Dev Ctries. 2011;5(3):231-4.

11. Antonello VS, Zenkner Fde M, Franca J, Santos BR. Enterococcus gallinarum meningitis in an immunocompetent host: a case report. Rev Inst Med Trop Sao Paulo. 2010;52(2):111-2.

12. Roca B, Pesudo JV, Gonzalez-Darder JM. Meningitis caused by enterococcus gallinarum after lumbar drainage of cerebrospinal fluid. Eur J Intern Med. 2006;17(4):298-9.

13. Li XQ, Fan SJ, Liu L, Xiao M, Lin XJ. Enterococcus gallinarum meningitis: a case report. Zhongguo Dang Dai Er Ke Za Zhi. 2013;15(12):1096-7.

\section{Abbreviations}

BG: Blood glucose; CRP: C reactive protein; CT: Computed tomography; FBG: Fasting blood glucose; i.v.: Intravenous; MIC: Minimal inhibitory concentration; MRA: Magnetic Resonance Angiography; MRI: Magnetic Resonance Imaging; MRV: Magnetic Resonance Venography; R: Resistance; RBC: Red Blood Cell; RBG: Random blood glucose; S: Sensitive; VP shunt: Ventriculoperitoneal shunt; WBC: White blood cell 